\title{
Single-Chamber Microbial Fuel Cell with Multiple Plates of Bamboo Charcoal Anode: Performance Evaluation
}

\author{
Chikashi Sato ${ }^{1, *}$, N. Evelin Paucar ${ }^{1}$, Steve Chiu ${ }^{1}$, Muhammad Z. I. M. Mahmud ${ }^{1}$ and John Dudgeon ${ }^{2}$ \\ 1 Department of Civil and Environmental Engineering, Idaho State University, 921 South 8th Avenue, \\ Stop 8060, Pocatello, ID 83209, USA; evelinpaucardelac@isu.edu (N.E.P.); stevechiu@isu.edu (S.C.); \\ mahmmuha@isu.edu (M.Z.I.M.M.) \\ 2 Department of Anthropology, Idaho State University, 921 South 8th Avenue, Stop 8060, \\ Pocatello, ID 83209, USA; johndudgeon@isu.edu \\ * Correspondence: chikashisato@isu.edu; Tel.: +1-208-282-4389
}

Citation: Sato, C.; Paucar, N.E.; Chiu,

S.; Mahmud, M.Z.I.M.; Dudgeon, J.

Single-Chamber Microbial Fuel Cell with Multiple Plates of Bamboo Charcoal Anode: Performance Evaluation. Processes 2021, 9, 2194. https://doi.org/10.3390/pr9122194

Academic Editors: Alfredo Iranzo and Domenico Frattini

Received: 30 September 2021

Accepted: 3 December 2021

Published: 6 December 2021

Publisher's Note: MDPI stays neutral with regard to jurisdictional claims in published maps and institutional affiliations.

Copyright: (C) 2021 by the authors Licensee MDPI, Basel, Switzerland This article is an open access article distributed under the terms and conditions of the Creative Commons Attribution (CC BY) license (https:// creativecommons.org/licenses/by/ $4.0 /)$

\begin{abstract}
In this study, three single-chamber microbial fuel cells (MFCs), each having Pt-coated carbon cloth as a cathode and four bamboo charcoal (BC) plates as an anode, were run in a fed-batch mode, individually and in series. Simulated potato-processing wastewater was used as a substrate for supporting the growth of a mixed bacterial culture. The maximum power output increased from $0.386 \mathrm{~mW}$ with one MFC to $1.047 \mathrm{~mW}$ with three MFCs connected in series. The maximum power density, however, decreased from $576 \mathrm{~mW} / \mathrm{m}^{2}$ (normalized to the cathode area) with one MFC to $520 \mathrm{~mW} / \mathrm{m}^{2}$ with three MFCs in series. The experimental results showed that power can be increased by connecting the MFCs in series; however, choosing low resistance BC is crucial for increasing power density.
\end{abstract}

Keywords: microbial fuel cell; bamboo charcoal; potato wastewater; in-series connection

\section{Introduction}

Microbial fuel cells (MFCs) are bio-electrochemical devices capable of directly converting chemical energy to electrical energy using microorganisms as a catalyst [1-5]. This ability has been explored to generate electricity using wastewater as an energy source, while simultaneously treating wastewater [6-11].

MFCs are fundamentally classified into dual-chamber (or two-chamber) and singlechamber MFCs. The dual-chamber MFC consists of an anode chamber and cathode chamber. The anode chamber contains an anode electrode, microorganisms (biocatalysts), and anolyte (substrate, fuel source), while the cathode chamber houses a cathode electrode and catholyte. The two chambers are interfaced by a cation-specific or proton exchange membrane (PEM), and connected with an external circuit (conductive wire). In the singlechamber MFC design, the cathode chamber, catholyte, and PEM are removed, and one side of the cathode is directly exposed to oxidants, usually to the atmosphere (air cathode), and the other side to the anolyte. The air cathode allows oxygen $\left(\mathrm{O}_{2}\right)$ in the air to contact with protons $\left(\mathrm{H}^{+}\right)$to form water $\left(\mathrm{H}_{2} \mathrm{O}\right)$ at the cathode surface. The present study used the single-chamber air-cathode MFC, as it has several advantages over the dual-chamber MFC, including (i) reduced total MFC volume, (ii) reduced internal resistance, (iii) simpler operation and maintenance, (iv) lower construction costs, and (v) an enhanced $\mathrm{O}_{2}$ reduction rate on the cathode owing to freely available $\mathrm{O}_{2}$ in the air [12-15]. Although considerable progress and advancement has been made in recent years, the MFC performance is still insufficient for large-scale industrial applications.

Electrodes are key MFC components that have been heavily investigated to improve the performance and reduce manufacturing cost with the aim of scaling up of MFC systems [16]. Typically, conventional carbon-based materials, including graphite, carbon cloth, carbon felt, and carbon brush, are widely used for an anode as they can provide good biocompatibility [17]. Graphite has been used in various forms, including 
plates [18], paper [19], rods [6,20,21], foil [21], granules [22-24], particles [25], woven form [26], felt [27-29], foam [20], fiber [30], and fiber brush [31]. Other carbon-based materials that have been used in MFCs are carbon cloth [8,32-38], carbon felt [39,40], carbon paper ([7,21,41-49], carbonized cardboard [50-54], carbon rod [21], carbon mesh [55,56], carbon fiber veil [21], granular-activated carbon [57,58], biochar [57,59], reticulated vitreous carbon $[60,61]$, graphene $[19,62,63]$, carbon nanotubes [64,65], and bamboo charcoal $[66,67]$.

Among many factors, the oxidation of substrate and transferring electrons to the anode by electroactive bacteria $(\mathrm{EAB})$ have been conceived as the main rate-limiting steps $[15,68]$. To improve interactions between the EAB and anode surface, the electrodes were frequently prepared by various physical and/or chemical treatments that require laborious procedures. Examples of modified carbon materials that have been explored include graphite incorporated with manganese ion [26], carbon paper with coatings of vapor-deposited iron oxide [69], graphite with electrodeposition of platinum black, coated with polymer [70,71], heat-treated carbon cloth [10], ammonia-treated carbon cloth [34], polypyrrole-coated carbon [72], carbon felts doped with quinone derivatives [73], carbon nanofiber nonwovens [74], gold-sputtered carbon paper [75], and bamboo charcoal doped with ammonium phosphate [76]. The present study employed bamboo charcoal as an anode without treatment. It is desirable to use carbonized materials without chemical treatment because the effectiveness of chemically treated electrodes is likely short-lived, the treatment procedures are laborious and costly, and disposal of waste chemicals is burdensome. Although a multitude of carbon-based anode materials has been investigated, only a few studies have used bamboo charcoal as electrodes.

\section{Materials and Methods}

\subsection{MFC Design and Construction}

Three air-cathode single-chamber MFCs, namely MFC 1, MFC 2, and MFC 3, were constructed and operated in a fed-batch cyclic mode. Specifically, the body of each MFC was constructed using acrylic sheets $(0.6 \mathrm{~cm}$ thickness), which were cut and fastened together (Figure 1a). The outside dimension of each fuel cell is $13 \mathrm{~cm}$ long, $9 \mathrm{~cm}$ wide, and $11 \mathrm{~cm}$ in height. The top and cathode side covers can be detached from the main body so that the MFC can be cleaned and the cathode can be replaced when needed. Two holes were tapped on the top of the MFC to allow for the removal of a spent substrate solution and the feeding of a fresh solution. These holes were obturated during the operation to maintain an anaerobic condition.

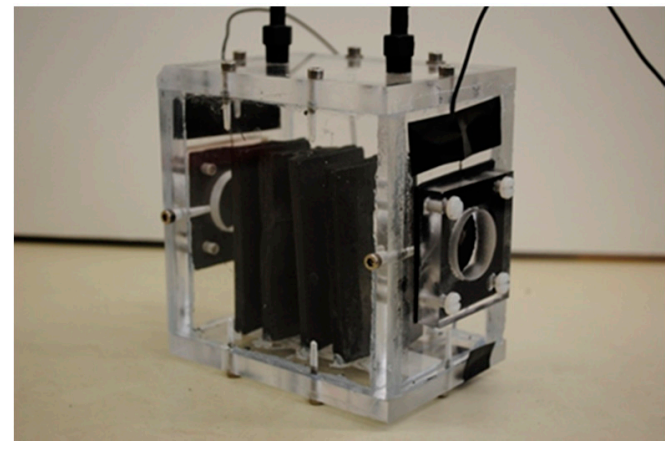

(a)

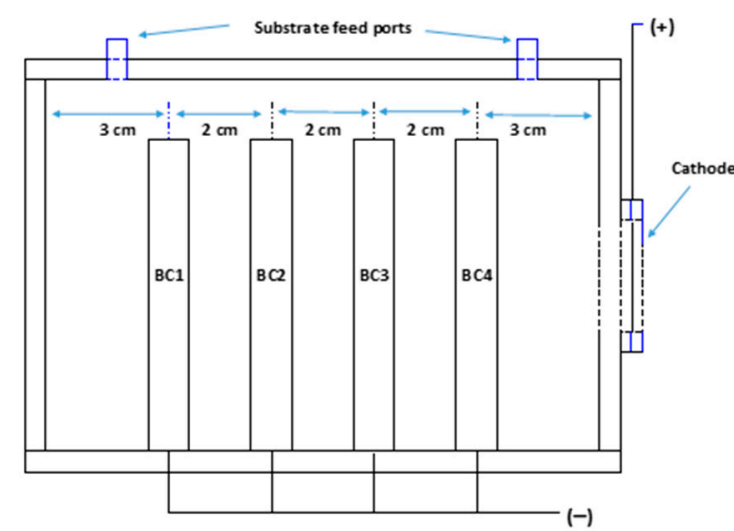

(b)

Figure 1. Single-chamber air-cathode MFC with a Pt-coated carbon cloth cathode and bam-boo charcoal (BC) anode: (a) photo; (b) positioning of bamboo charcoal plates.

In order to expose the cathode to the atmosphere, a circular opening ( $3 \mathrm{~cm}$ diameter) was drilled into the acrylic sheet that holds the cathode. The cathode electrode was made 
of carbon cloth with platinum loadings of $0.3 \mathrm{mg} / \mathrm{cm}^{2}$ (Fuel Cell Earth, Woburn, MA, USA). The apparent surface area (one side) of the cathode was $6.7 \mathrm{~cm}^{2}$.

The anode electrode was made of bamboo charcoal (Mt Meru Pte, Singapore). Four plates of bamboo charcoal, namely $\mathrm{BC} 1, \mathrm{BC} 2, \mathrm{BC} 3$, and $\mathrm{BC} 4$, were placed as the anode inside the MFC body (Figure $1 \mathrm{~b}$ ). The $\mathrm{BC}$ plates were spaced $2 \mathrm{~cm}$ from each other, and the distance between the cathode and the nearest $B C$ plate was $3 \mathrm{~cm}$. Specifications of the BC anode plates are presented in Table $\mathrm{S} 1$, as supporting information. These $\mathrm{BC}$ plates were selected among the $\mathrm{BC}$ plates of different resistances on the basis of low resistance. The BC surface was visualized using a scanning electron microscope (SEM) (Quanta 200 FEG, FEI Co., Czech Republic). The apparent (geometric) surface area of each BC anode plate was typically $75 \mathrm{~cm}^{2}$ ranging from 64 to $81 \mathrm{~cm}^{2}$, and the lengthwise and widthwise resistance of the $B C$ anode plates was $30 \Omega$ on average in a range from 16 to $54 \Omega$. The average resistance of the BC electrodes of MFC 1 , MFC 2, and MFC 3 were 26,24 , and $40 \Omega$, respectively. A stainless-steel wire lead was attached to each electrode using conductive epoxy adhesive (MG Chemicals, Ontario, Canada), and its surface was covered by nonconductive epoxy putty (J-B Weld, Coopersburg, PA, USA) for reinforcement. For each BC anode plate, a hole was drilled in the bottom of the MFC to allow the wire leads to pass through the bottom sheet to connect the electrodes externally. The anode and the cathode were connected through an external resistor to close the circuit. After the installation of the $\mathrm{BC}$ anode plates, the working volumes (or anolyte volumes) of MFC-1, MFC-2, and MFC-3 were 530, 530, and $500 \mathrm{~mL}$, respectively.

\subsection{Experimental Conditions and Analyses}

Simulated potato-processing wastewater was used as a substrate (anolyte). To prepare the wastewater, concentrated potato extract obtained from a local food processing plant in Idaho Falls, Idaho, USA, was diluted to the desired concentration (approximately $1000 \mathrm{mg} / \mathrm{L}$ ) of chemical oxygen demand (COD) using a pH-7 phosphate buffer solution. The potato extract was analyzed by ICP-MS (X-Series II, Thermo Scientific, Germany), and results are presented in Table S2, as supporting information. The wastewater was autoclaved at $121{ }^{\circ} \mathrm{C}$ for $20 \mathrm{~min}$ to assure that the substrate was free from active microbes, and stored in a refrigerator at $4{ }^{\circ} \mathrm{C}$ until used.

The bacterial culture used in this study originated from an anaerobic digester at the Wastewater Treatment Plant in the City of Pocatello, Idaho. The anaerobic mixed bacterial community was acclimated in sterilized synthetic potato-processing wastewater for more than 10 years by the feeding aforementioned sterilized substrate every two weeks to a month, and thus the inoculum was considered to be fully acclimated. The previous study revealed that microbial species present in the anode chamber were predominantly within the phyla of Proteobacteria, Firmicutes, and Bacteroidetes [77].

The organic strength of the wastewater (substrate solution) was measured as COD at the beginning and end of the run cycle. The loss of anolyte (wastewater) in the chamber was compensated by filling deionized water before taking samples. The COD measurement was carried out using the USEPA Reactor Digestion Method (HACH, USA). Wastewater samples were filtered using a $0.2 \mu \mathrm{m}$ Millex-VV filter (Millipore, France) before the COD analysis. The removal efficiency of individual MFC was approximately $80 \%$ in one cycle run.

\subsection{MFC Operation and Monitoring}

The MFCs were run with five different settings: (1) MFC 1 only; (2) MFC 2 only; (3) MFC 3 only; (4) MFC 1 and MFC 2 in-series (noted as MFC 1-2), and (5) MFC 1, MFC 2, and MFC 3 in-series (noted as MFC 1-2-3). The MFCs were operated in a fed-batch mode at $30 \pm 2{ }^{\circ} \mathrm{C}$. The MFCs were considered to have reached a quasi-steady state when a stable voltage cycle was achieved, i.e., the MFCs produced similar voltage profiles and repeated at least three cycles. When the system reached a stable condition and voltage reached a high plateau region, the external resistance in the circuit was varied in a range from 20 to $800 \Omega$ to obtain the maximum power output. 
The voltage produced by the MFCs was measured using a data acquisition system (DAS) and continuously recorded every $15 \mathrm{~min}$. The DAS consisted of a computer equipped with a data acquisition board (PCl-6024E, National Instrument, Austin, TX, USA) and an external connection block (SCB-6024E, National Instrument). The DAS was controlled by LabView-2014 (National Instruments, Austin, TX, USA). The potential difference between the cathode $(+)$ and anode $(-)$ is voltage $(\mathrm{V})$ across a resistor $(\mathrm{R})$. Current (I) was calculated from Ohm's law: $\mathrm{I}=\mathrm{V} / \mathrm{R}$. Power $(\mathrm{P})$ was calculated by $\mathrm{P}=\mathrm{I} \cdot \mathrm{V}$ or $\mathrm{P}=\mathrm{V}^{2} / \mathrm{R}$. To analyze the performance of MFC, power density and polarization curves were developed. Current and power densities were normalized to the cathode area, anode area, and effective chamber (anolyte) volume. The vales of internal resistance were determined according to the maximum power transfer theorem [78].

\section{Results and Discussion}

\subsection{Bamboo Charcoal Anode}

As was described previously, a large variety of carbon materials have been studied for anode electrodes to improve MFC performance. The present study used bamboo charcoal (BC) for the anode. In the MFC design, electrodes are desired to have the following characteristics: (i) high electrical conductivity and low resistance; (ii) high mechanical strength; (iii) strong biocompatibility, (iv) high chemical stability and corrosion resistance, (v) large surface area, (vi) low cost, and vii) environmental friendliness [1]. Bamboo charcoal meets most of the aforementioned characteristics $[66,67,76,79-88]$. Figure 2 shows SEM images of the external surface and cross-section of the BC anode. The electron micrographs show that the BC used in this study has a rough fiber-like external surface (Figure 2a) and is comprised of dense round to hexagonal tubes from 20 to $500 \mu \mathrm{m}$ in diameter, arranged in a honeycomb-like pattern (Figure $2 b$ ). The interconnected porous architecture can provide a large surface area for microbial cell attachment and biofilm growth, and facilitates the diffusion of nutrients and protons. These characteristics are essential to the anode for high performance. The major drawback is that being a natural plant, the specifications of the $\mathrm{BC}$ such as the thickness and resistance can vary (Table S1). It should be noted that BC plates used in MFC 3 had noticeably larger resistances compared to those of MFC 1 and MFC 2.

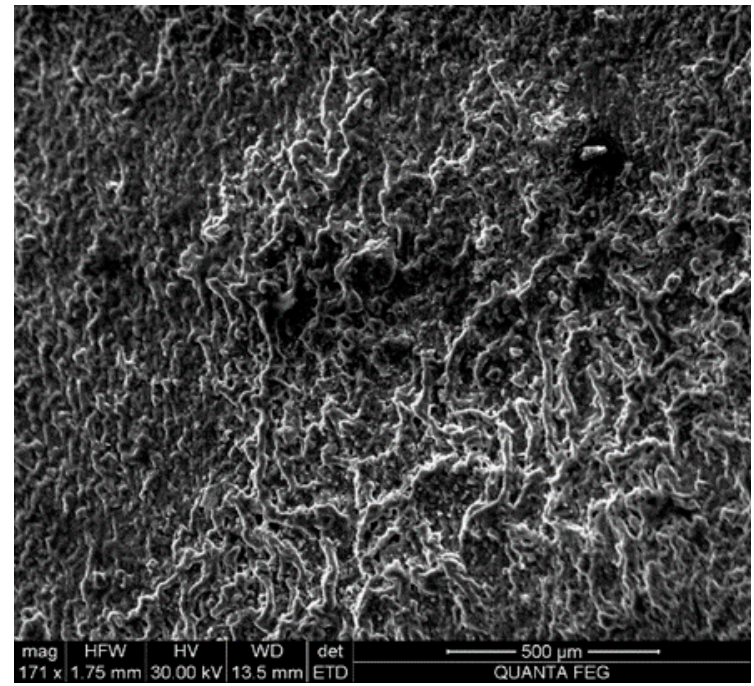

(a)

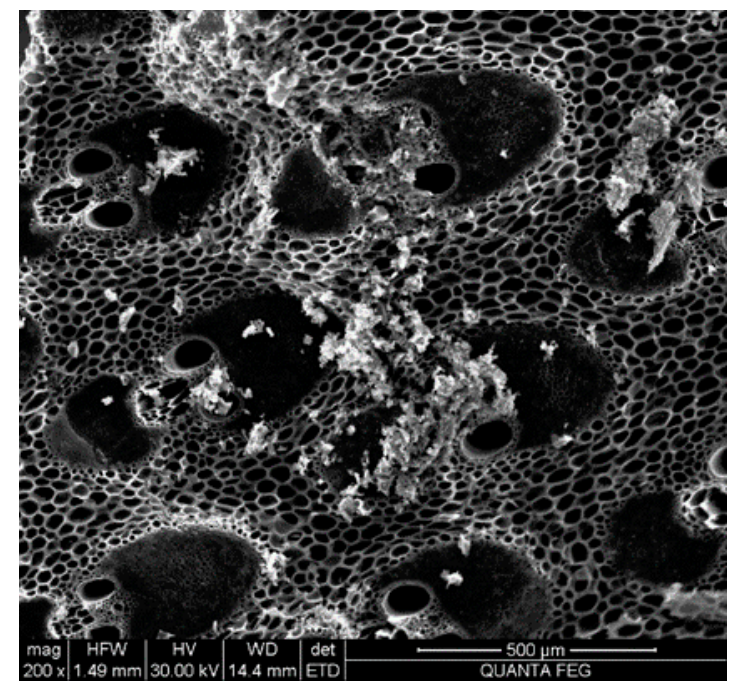

(b)

Figure 2. SEM images of bamboo charcoal anode: (a) external surface; (b) cross section.

In a study with BC and carbon fiber anodes, Moqsud et al. [67] found that bamboo charcoal was an effective anode material. A comparison of tubular BC with tubular graphite showed that BC was a better anode material in terms of surface roughness, biocompatibility, electron transfer, and total internal resistance [89]. Additional advantages of using bamboo 
charcoal are that bamboo is a fast-growing plant [90] and thus it sequesters $\mathrm{CO}_{2}$ rapidly from the atmosphere, stabilizing carbon in a solid form [91]. Bamboo charcoal can be easily manufactured at low cost and with minimal carbon footprint, reused, and disposed of safely (e.g., as biochar) as it is a natural material.

\subsection{MFC Performance}

The performance of MFCs is generally expressed in either power output or power density normalized to the cathode area, anode area, or effective anode chamber (or anolyte) volume. Preliminary examinations of the MFC 1, MFC 2, and MFC 3 runs in the present study showed that these four expressions are comparable (see Figure S1, supporting information). Hence, in this paper, the power density and current density were normalized to the projected cathode area. Note that all the MFCs used in this study had the same cathode area $\left(6.7 \times 10^{-4} \mathrm{~m}^{2}\right)$.

The experimental results are analyzed in two stages. Firstly, the performance of MFC 1, MFC 2, and MFC 3 are analyzed individually. Figure 3a shows plots of power $(\mathrm{mW})$ against corresponding current density $\left(\mathrm{mA} / \mathrm{m}^{2}\right)$ for MFC1 (circles), MFC 2 (squares), and MFC 3 (triangles). Lines are third-order polynomial fits to guide the eyes. As is seen, MFC 1 and MFC 2 produced similar power curves, while MFC 3 exhibited a considerably smaller power curve. The maximum power achieved by MFC 1 and MFC 2 is 0.386 and $0.383 \mathrm{~mW}$ at a current density of $3.27 \times 10^{3}$ and $2.67 \times 10^{3} \mathrm{~mA} / \mathrm{m}^{2}$, respectively. The maximum power yielded by MFC 3 is $0.284 \mathrm{~mW}$ at a current density of $2.09 \times 10^{3} \mathrm{~mA} / \mathrm{m}^{2}$. The trends of polarization for MFC 1 , MFC 2, and MFC 3 are shown in Figure $3 b$. The polarization curves produced by MFC 1 and MFC 2 are nearly identical, whereas the voltage produced by MFC 3 is noticeably smaller, consistent with the power curves. This smaller voltage produced by MFC 3 is most likely attributed to the larger internal resistance of MFC 3.
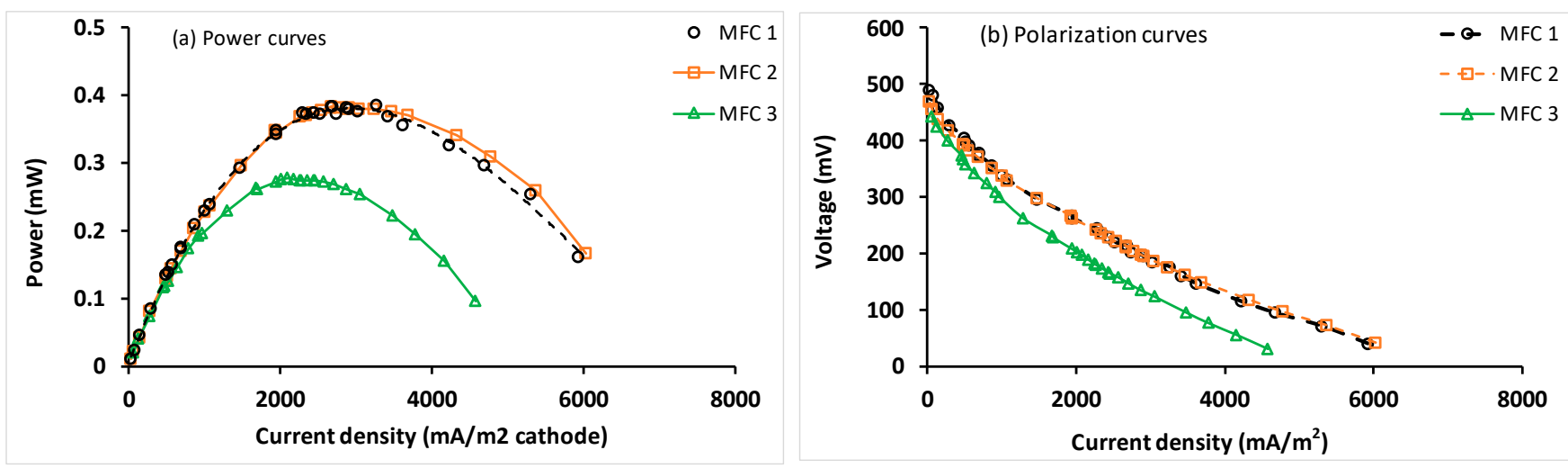

Figure 3. Performance of MFC 1, MFC 2, and MFC 3 individually: (a) power curves and (b) polarization curves.

Figure 4 shows the correlation between current (at the maximum power) and internal resistance. As is seen, current and internal resistance are inversely related. In a comparison of MFC 1 and MFC 3, a 51\% increase in internal resistance resulted in a 28\% decrease in current. 


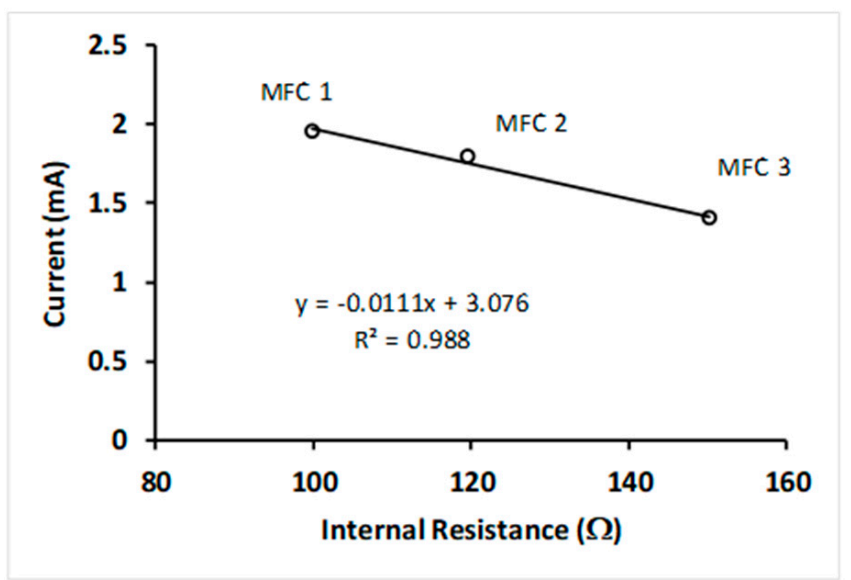

Figure 4. Current vs. internal resistance in MFC 1, MFC 2 and MFC 3.

Secondly, the performance of the MFCs connected in series is examined. Figure 5a shows the power curves for MFC 1 (circle), MFC 1-2 (square), and MFC 1-2-3 (triangle). As the number of the MFCs was increased, the power output increased, and the maximum power shifted to the lower current density and larger voltage (Figure $5 b$ ). The maximum power output increased from $0.386 \mathrm{~mW}$ (at $3.27 \times 10^{3} \mathrm{~mA} / \mathrm{m}^{2}$ ), $0.875 \mathrm{~mW}$ (at $1.75 \times 10^{3} \mathrm{~mA} / \mathrm{m}^{2}$ ) to $1.047 \mathrm{~mW}$ (at $1.14 \times 10^{3} \mathrm{~mA} / \mathrm{m}^{2}$ ) with the MFC 1, MFC 1-2, and MFC 1-2-3 settings, respectively. The increase of the power output from the MFC 1 to MFC 1-2 setting was $120 \%$, whereas the power increase from the MFC 1-2 setting to the MFC 1-2-3 setting was only $20 \%$. This smaller power increase in the MFC 1-2-3 setting is most likely attributed to the larger internal resistance of MFC 3. Theoretically, if two MFCs are connected in series, the system can increase the power output by increasing the voltage without increasing the current (92). However, MFC 1-2 produced approximately $15 \%$ less voltage than the theoretically available voltage, whereas it produced about $35 \%$ more current than the theoretical current. Overall, MFC 1-2 produced more than $20 \%$ greater power than the theoretical additive power. The decrease in the voltage is likely due to voltage reversal (VR), as this is a common phenomenon in stacked MFCs and MFCs in series [92]. The potential causes of VR are (a) kinetic imbalances between the MFCs in series [93], and (b) substrate limitation from microbial starving conditions [23,94]. Several VR control methods have been discussed and proposed by Kim et al. [92]. The increase in the current could be attributed to the properties of $\mathrm{BC}$ or the arrangement of the $\mathrm{BC}$ plates. A slightly super-linear increase in power output by stacking individual MFC units has been reported [95]. Nevertheless, the effects of the BC material and multiple BC plates on the MFC performance require further investigation.
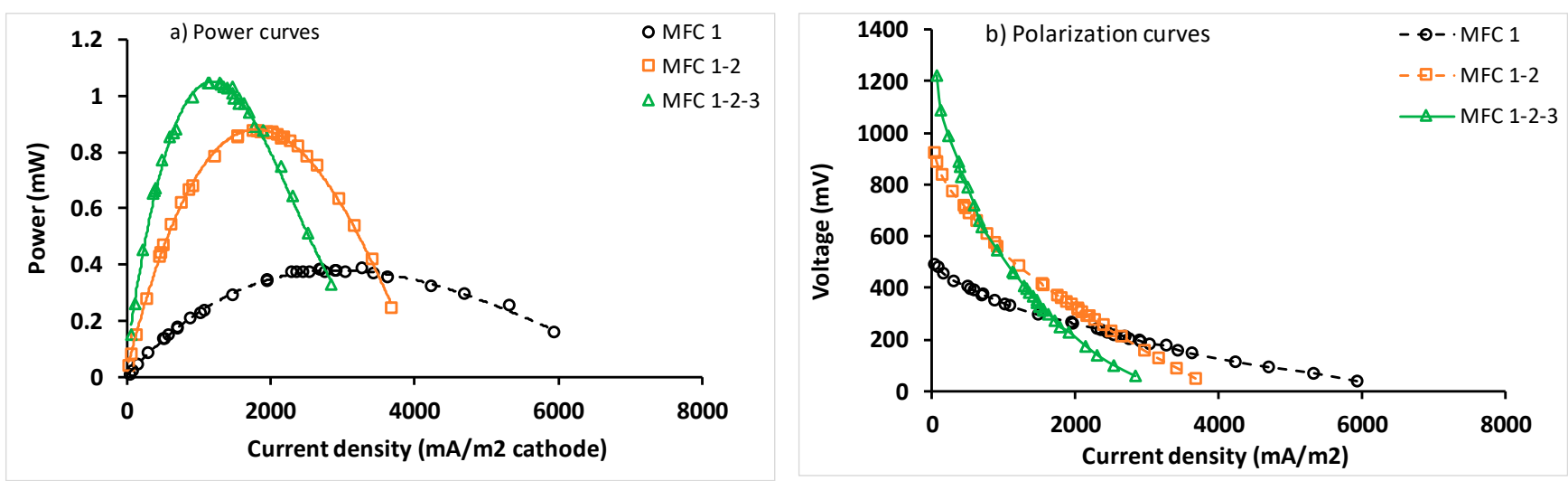

Figure 5. Performance of the MFCs in series: (a) power curves and (b) polarization curves for the MFC 1, MFC 1-2, and MFC 1-2-3 settings. 
Figure 6 shows the power density curves $\left(\mathrm{mW} / \mathrm{m}^{2}\right)$ for the MFC 1, MFC 1-2, and MFC 1-2-3 settings. As is seen, the power density increased from the MFC 1 to the MFC 1-2 setting but decreased in the MFC 1-2-3 setting. Although the power output was increased by adding MFCs in series, the increase in power by MFC 3 was not large enough to offset the increase in the cathode area. The cathode area increased from $6.7 \times 10^{-4} \mathrm{~m}^{2}$ to $1.34 \times 10^{-3} \mathrm{~m}^{2}$ to $2.01 \times 10^{-3} \mathrm{~m}^{2}$ in the MFC 1, MFC 1-2, and MFC 1-2-3 runs, respectively. Consequently, MFC 1-2-3 exhibited the lowest power density $\left(520 \mathrm{~mW} / \mathrm{m}^{2}\right.$ cathode at $\left.1.14 \times 10^{3} \mathrm{~mA} / \mathrm{m}^{2}\right)$ as compared to MFC $1\left(576 \mathrm{~mW} / \mathrm{m}^{2}\right.$ at $\left.3.27 \times 10^{3} \mathrm{~mA} / \mathrm{m}^{2}\right)$ and MFC 1$2\left(653 \mathrm{~mW} / \mathrm{m}^{2}\right.$ at $\left.1.75 \times 10^{3} \mathrm{~mA} / \mathrm{m}^{2}\right)$. The results indicate that the power output increases with an increasing number of MFCs in-series; however, the MFC that behaves poorly affects negatively the overall performance of the MFC system.

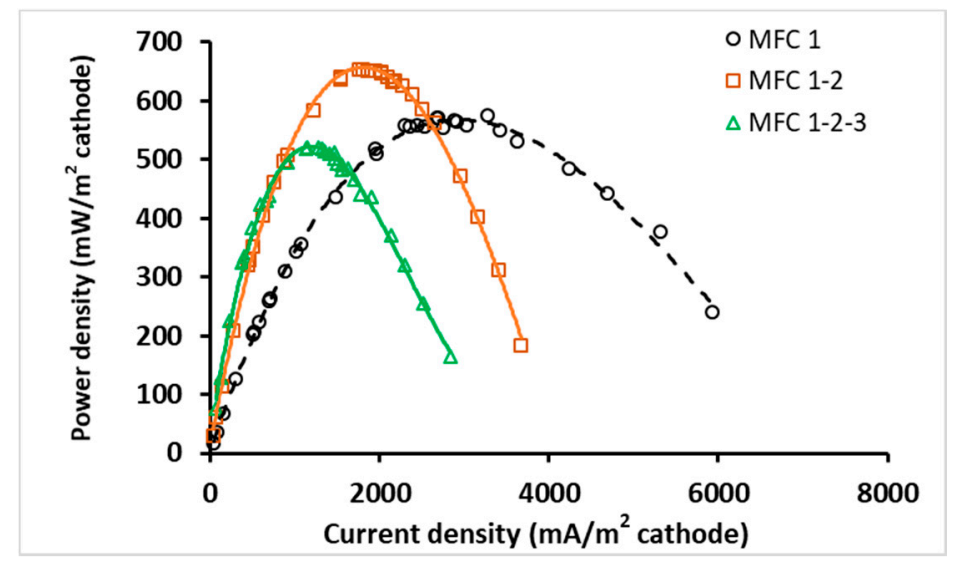

Figure 6. Power density for the MFC 1, MFC 1-2, and MFC 1-2-3 settings.

One of the factors that limit power output by MFCs is their internal resistance, which is comprised of activation (or charge transfer) resistance, ohmic (or solution) resistance, and concentration (or diffusion) resistance [96]. The ohmic resistance represents the resistance of solution, electrode materials, and membrane. In a single-chamber air-cathode MFC, the sources of ohmic resistance are mainly the electrodes and anolyte. Figure 7 shows the relation between the internal resistance and $\mathrm{BC}$ plate resistance. Note that the $\mathrm{BC}$ anode resistances were measured before they were placed inside the MFC chamber. As is seen, the internal resistance was smaller than the $\mathrm{BC}$ anode resistance, indicating that the $\mathrm{BC}$ plates became more conductive, likely due to the establishment of EAB biofilm.

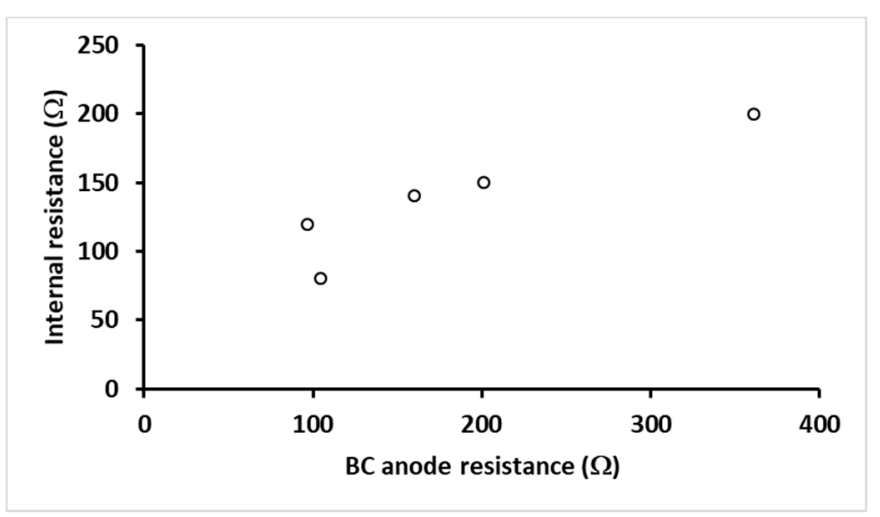

Figure 7. Internal resistance vs. bamboo charcoal anode resistance.

\section{Conclusions}

This study focused on the single-chamber air-cathode MFCs with the bamboo charcoal (BC) anode and Pt-coated carbon cloth cathode. Three MFCs were run in a fed-batch mode, 
individually and in series using synthetic potato-processing wastewater as an anolyte. The maximum power output increased from $0.386 \mathrm{~mW}\left(\right.$ at $\left.3.27 \times 10^{3} \mathrm{~mA} / \mathrm{m}^{2}\right)$ with one MFC to $1.047 \mathrm{~mW}$ (at $1.14 \times 10^{3} \mathrm{~mA} / \mathrm{m}^{2}$ ) with three MFCs connected in series. The maximum power density, however, decreased from $576 \mathrm{~mW} / \mathrm{m}^{2}\left(\right.$ at $3.27 \times 10^{3} \mathrm{~mA} / \mathrm{m}^{2}$ ) with one MFC to $520 \mathrm{~mW} / \mathrm{m}^{2}$ cathode (at $1.14 \times 10^{3} \mathrm{~mA} / \mathrm{m}^{2}$ ) with three MFCs in series. The experimental results showed that power can be increased by connecting MFCs in series; however, choosing high-quality (low resistance) $\mathrm{BC}$ charcoal is crucial for increasing power density.

Supplementary Materials: The following are available online at https://www.mdpi.com/article/ 10.3390/pr9122194/s1: Table S1: Dimensions and resistance of bamboo charcoal analysis; Table S2: Concentrations of inorganic constituents in potato extracts (ICP analysis results); Figure S1: Power and power density curves for MFC 1: (a) power; (b) power density normalized to the cathode area; (c) anode area, and (d) anolyte volume.

Author Contributions: Conceptualization, C.S.; methodology, C.S., N.E.P., M.Z.I.M.M. and J.D.; validation, C.S.; formal analysis, C.S.; investigation, C.S., N.E.P., S.C., M.Z.I.M.M. and J.D.; resources, C.S. and S.C.; data curation, C.S. and M.Z.I.M.M.; writing-original draft preparation, C.S.; writing—-review and editing, C.S. and N.E.P.; visualization, C.S.; supervision, C.S. and S.C.; project administration, C.S. and S.C.; funding acquisition, C.S. and S.C. All authors have read and agreed to the published version of the manuscript.

Funding: This research received no external funding.

Institutional Review Board Statement: Not applicable.

Informed Consent Statement: Not applicable.

Data Availability Statement: The data presented in this study are available on request from the corresponding author. The data are not publicly available due to potential proprietary information.

Acknowledgments: The authors would like to express their sincere appreciation to the College of Science and Engineering at Idaho State University for their support.

Conflicts of Interest: The authors declare no conflict of interest.

\section{References}

1. Logan, B.E.; Hamelers, B.; Rozendal, R.; Schröder, U.; Keller, J.; Freguia, S.; Aelterman, P.; Verstraete, W.; Rabaey, K. Microbial fuel cells: Methodology and technology. Environ. Sci. Technol. 2006, 40, 5181-5192. [CrossRef] [PubMed]

2. Rahimnejad, M.; Ghoreyshi, A.A.; Najafpour, G.D.; Younesi, H.; Shakeri, M. A novel microbial fuel cell stack for continuous production of clean energy. Int. J. Hydrogen Energy 2012, 37, 5992-6000. [CrossRef]

3. Oon, Y.L.; Ong, S.A.; Ho, L.N.; Wong, Y.S.; Oon, Y.S.; Lehl, H.K.; Thung, W.E. Hybrid system up-flow constructed wetland integrated with microbial fuel cell for simultaneous wastewater treatment and electricity generation. Bioresour. Technol. 2015, 186, 270-275. [CrossRef]

4. Callegari, A.; Cecconet, D.; Molognoni, D.; Capodaglio, A.G. Sustainable processing of dairy wastewater: Long-term pilot application of a bio-electrochemical system. J. Clean. Prod. 2018, 189, 563-569. [CrossRef]

5. Ye, Y.; Ngo, H.H.; Guo, W.; Chang, S.W.; Nguyen, D.D.; Liu, Y.; Nghiem, L.D.; Zhang, X.; Wang, J. Effect of organic loading rate on the recovery of nutrients and energy in a dual-chamber microbial fuel cell. Bioresour. Technol. 2019, 281, 367-373. [CrossRef] [PubMed]

6. Liu, H.; Ramnarayanan, R.; Logan, B.E. Production of electricity during wastewater treatment using a single chamber microbial fuel cell. Environ. Sci. Technol. 2004, 38, 2281-2285. [CrossRef]

7. Oh, S.; Logan, B.E. Hydrogen and electricity production from a food processing wastewater using fermentation and microbial fuel cell technologies. Water Res. 2005, 39, 4673-4682. [CrossRef] [PubMed]

8. Cheng, S.; Liu, H.; Logan, B.E. Increased performance of single-chamber microbial fuel cells using an improved cathode structure. Electrochem. Commun. 2006, 8, 489-494. [CrossRef]

9. Ahn, Y.; Logan, B.E. Effectiveness of domestic wastewater treatment using microbial fuel cells at ambient and mesophilic temperatures. Bioresour. Technol. 2010, 101, 469-475. [CrossRef] [PubMed]

10. Liu, G.; Yates, M.D.; Cheng, S.; Call, D.F.; Sun, D.; Logan, B.E. Examination of microbial fuel cell start-up times with domestic wastewater and additional amendments. Bioresour. Technol. 2011, 102, 7301-7306. [CrossRef] [PubMed]

11. Oliveira, V.B.; Simões, M.; Melo, L.F.; Pinto, A.M.F.R. A 1D mathematical model for a microbial fuel cell. Energy 2013, 61, 463-471. [CrossRef] 
12. Ou, S.; Kashima, H.; Aaron, D.S.; Regan, J.M.; Mench, M.M. Multi-variable mathematical models for the air-cathode microbial fuel cell system. J. Power Sources 2016, 314, 49-57. [CrossRef]

13. Singh, S.; Modi, A.; Verma, N. Enhanced power generation using a novel polymer-coated nanoparticles dispersed-carbon micro-nanofibers-based air-cathode in a membrane-less single chamber microbial fuel cell. Int. J. Hydrogen Energy 2016, 41, 1237-1247. [CrossRef]

14. Li, M.; Zhang, H.G.; Xiao, T.F.; Zhang, B.P.; Yan, J.; Chen, D.Y.; Chen, Y.H. Rose flower-like nitrogen-doped NiCo2O4/carbon used as cathode electrocatalyst for oxygen reduction in air cathode microbial fuel cell. Electrochim. Acta 2017, 258, 1219-1227. [CrossRef]

15. Geetanjali, R.; Rani, R.; Kumar, S. Enhanced performance of a single chamber microbial fuel cell using NiWO4/reduced graphene oxide coated carbon cloth anode. Fuel Cells 2019, 19, 299-308. [CrossRef]

16. Baudler, A.; Schmidt, I.; Langner, M.; Greiner, A.; Schroder, U. Does it have to be carbon? Metal anodes in microbial fuel cells and related bioelectrochemical systems. Energy Environ. Sci. 2015, 8, 2048-2055. [CrossRef]

17. Liu, X.; Zhao, X.; Yu, Y.Y.; Wang, Y.Z.; Shi, Y.T.; Cheng, Q.W.; Fang, Z.; Yong, Y.C. Facile fabrication of conductive polyaniline nanoflower modified electrode and its application for microbial energy harvesting. Electrochim. Acta 2017, 255, 41-47. [CrossRef]

18. Mohan, S.V.; Raghavulu, S.V.; Peri, D.; Sarma, P.N. Integrated function of microbial fuel cell (MFC) as bio-electrochemical treatment system associated with bioelectricity generation under higher substrate load. Biosens. Bioelectron. 2009, 24, $2021-2027$. [CrossRef]

19. Srikanth, S.; Marsili, E.; Flickinger, M.C.; Bond, D.R. Electrochemical characterization of Geobacter sulfurreducens cells immobilized on graphite paper electrodes. Biotechnol. Bioeng. 2008, 99, 1065-1073. [CrossRef]

20. Chaudhuri, S.K.; Lovley, D.R. Electricity generation by direct oxidation of glucose in mediatorless microbial fuel cells. Nat. Biotech. 2003, 21, 1229-1232. [CrossRef]

21. Liu, Y.; Harnisch, F.; Fricke, K.; Schröder, U.; Climent, V.; Feliu, J.M. The study of electrochemically active microbial biofilms on different carbon-based anode materials in microbial fuel cells. Biosens. Bioelectron. 2010, 25, 2167-2171. [CrossRef] [PubMed]

22. Clauwaert, P.; Van Der Ha, D.; Boon, N.; Verbeken, K.; Verhaege, M.; Rabaey, K.; Verstraete, W. Open air biocathode enables effective electricity generation with microbial fuel cells. Environ. Sci. Technol. 2007, 41, 7564-7569. [CrossRef] [PubMed]

23. Aelterman, P.; Rabaey, K.; Pham, H.T.; Boon, N.; Verstraete, W. Continuous electricity generation at high voltages and currents using stacked microbial fuel cells. Environ. Sci. Technol. 2006, 40, 3388-3394. [CrossRef]

24. Ryu, J.H.; Lee, H.L.; Lee, Y.P.; Kim, T.S.; Kim, M.K.; Anh, D.T.N.; Tran, H.T.; Ahn, D.H. Simultaneous carbon and nitrogen removal from piggery wastewater using loop configuration microbial fuel cell. Process Biochem. 2013, 48, 1080-1085. [CrossRef]

25. Sell, D.; Kraemer, P.; Kreysa, G. Use of an oxygen gas diffusion cathode and a three-dimensional packed bed anode in a bioelectrochemical fuel cell. Appl. Microbiol. Biotechnol. 1989, 31, 211-213. [CrossRef]

26. Park, D.; Zeikus, J. Impact of electrode composition on electricity generation in a single-compartment fuel cell using Shewanella putrefaciens. Appl. Microbiol. Biotechnol. 2002, 59, 58-61.

27. Kim, H.J.; Park, H.S.; Hyun, M.S.; Chang, I.S.; Kim, M.; Kim, B.H. A mediator-less microbial fuel cell using a metal reducing bacterium, Shewanella putrefaciens. Enzym. Microb. Technol. 2002, 30, 145-152. [CrossRef]

28. Kim, B.H.; Park, H.S.; Kim, H.J.; Kim, G.T.; Chang, I.S.; Lee, J.; Phung, N.T. Enrichment of microbial community generating electricity using a fuel-cell-type electrochemical cell. Appl. Microbiol. Biotechnol. 2004, 63, 672-681. [CrossRef]

29. An, J.; Kim, D.; Chun, Y.; Lee, S.J.; How, Y.N.G.; Chang, I.S. Floating-type microbial fuel cell (FT-MFC) for treating organiccontaminated water. Environ. Sci. Technol. 2009, 43, 1642-1647. [CrossRef] [PubMed]

30. Wrighton, K.C.; Thrash, J.C.; Melnyk, R.A.; Bigi, J.P.; Byrne-Bailey, K.G.; Remis, J.P.; Schichnes, D.; Auer, M.; Chang, C.J.; Coates, J.D. Evidence for direct electron transfer by a gram-positive bacterium isolated from a microbial fuel cell. Appl. Environ. Microbiol. 2011, 77, 7633-7639. [CrossRef]

31. Logan, B.; Cheng, S.; Watson, V.; Estadt, G. Graphite fiber brush anodes for increased power production in air-cathode microbial fuel cells. Environ. Sci. Technol. 2007, 41, 3341-3346. [CrossRef]

32. Cheng, S.; Liu, H.; Logan, B.E. Increased power generation in a continuous flow MFC with advective flow through the porous anode and reduced electrode spacing. Environ. Sci. Technol. 2006, 40, 2426-2432. [CrossRef]

33. Cheng, S.; Liu, H.; Logan, B.E. Power densities using different cathode catalysts (Pt and CoTMPP) and polymer binders (Nation and PTFE) in single chamber microbial fuel cells. Environ. Sci. Technol. 2006, 40, 364-369. [CrossRef] [PubMed]

34. Cheng, S.; Logan, B.E. Ammonia treatment of carbon cloth anodes to enhance power generation of microbial fuel cells. Electrochem. Commun. 2007, 9, 492-496. [CrossRef]

35. Ishii, S.; Watanabe, K.; Yabuki, S.; Logan, B.E.; Sekiguchi, Y. Comparison of electrode reduction activities of Geobacter sulfurreducens and an enriched consortium in an air-cathode microbial fuel cell. Appl. Environ. Microbiol. 2008, 74, 7348-7355. [CrossRef] [PubMed]

36. Wang, X.; Feng, Y.J.; Lee, H. Electricity production from beer brewery wastewater using single chamber microbial fuel cell. Water Sci. Technol. 2008, 57, 1117-1121. [CrossRef]

37. Feng, Y.; Wang, X.; Logan, B.E.; Lee, H. Brewery wastewater treatment using air-cathode microbial fuel cells. Appl. Microbiol. Biotechnol. 2008, 78, 873-880. [CrossRef] 
38. Martinez-Conesa, E.J.; Ortiz-Martinez, V.M.; Salar-Garcia, M.J.; De Los Rios, A.P.; Hernandez-Fernandez, F.J.; Lozano, L.J.; Godinez, C. A Box-Behnken design-based model for predicting power performance in microbial fuel cells using wastewater. Chem. Eng. Commun. 2017, 204, 97-104. [CrossRef]

39. Chae, K.J.; Choi, M.J.; Lee, J.W.; Kim, K.Y.; Kim, I.S. Effect of different substrates on the performance, bacterial diversity, and bacterial viability in microbial fuelcells. Bioresour. Technol. 2009, 100, 3518-3525. [CrossRef]

40. Massaglia, G.; Margaria, V.; Sacco, A.; Tommasi, T.; Pentassuglia, S.; Ahmed, D.; Mo, R.; Pirri, C.F.; Quaglio, M. In situ continuous current production from marine floating microbial fuel cells. Appl. Energy 2018, 230, 78-85. [CrossRef]

41. Liu, H.; Logan, B.E. Electricity generation using an air-cathode single chamber microbial fuel cell in the presence and absence of a proton exchange membrane. Environ. Sci. Technol. 2004, 38, 4040-4046. [CrossRef]

42. Kim, J.R.; Cheng, S.; Oh, S.E.; Logan, B.E. Power generation using different cation, anion, and ultrafiltration membranes in microbial fuel cells. Environ. Sci. Technol. 2007, 41, 1004-1009. [CrossRef]

43. Kim, J.R.; Jung, S.H.; Regan, J.M.; Logan, B.E. Electricity generation and microbial community analysis of alcohol powered microbial fuel cells. Bioresour. Technol. 2007, 98, 2568-2577. [CrossRef]

44. Lu, N.; Zhou, S.; Zhuang, L.; Zhang, J.; Ni, J. Electricity generation from starch processing wastewater using microbial fuel cell technology. Biochem. Eng. J. 2009, 43, 246-251. [CrossRef]

45. Min, B.; Cheng, S.; Logan, B.E. Electricity generation using membrane and salt bridge microbial fuel cells. Water Res. 2005, 39, 1675-1686. [CrossRef]

46. Min, B.; Kim, J.; Oh, S.; Regan, J.M.; Logan, B.E. Electricity generation from swine wastewater using microbial fuel cells. Water Res. 2005, 39, 4961-4968. [CrossRef]

47. Min, B.; Logan, B.E. Continuous electricity generation from domestic wastewater and organic substrates in a flat plate microbial fuel cell. Environ. Sci. Technol. 2004, 38, 5809-5814. [CrossRef]

48. Oh, S.E.; Logan, B.E. Proton exchange and electrode surface areas as factors that affect power generation in microbial fuel cells. Appl. Microbiol. Biotechnol. 2006, 70, 162-169. [CrossRef]

49. Zhang, Y.; Min, B.; Huang, L.; Angelidaki, I. Generation of electricity and analysis of microbial communities in wheat straw biomass-powered microbial fuel cells. Appl. Environ. Microbiol. 2009, 75, 3389-3395. [CrossRef]

50. Chen, S.L.; He, G.H.; Liu, Q.; Harnisch, F.; Zhou, Y.; Chen, Y.; Hanif, M.; Wang, S.Q.; Peng, X.W.; Hou, H.Q. Layered corrugated electrode macrostructures boost microbial bioelectrocatalysis. Energy Environ. Sci. 2012, 5, 9769-9772. [CrossRef]

51. Kretzschmar, J.; Riedl, S.; Brown, R.K.; Schroder, U.; Harnisch, F. eLatrine: Lessons learned from the development of a low-tech MFC based on cardboard electrodes for the treatment of human feces. J. Electrochem. Soc. 2017, 164, H3065-H3072. [CrossRef]

52. Liao, Q.; Zhang, J.; Li, J.; Ye, D.D.; Zhu, X.; Zhang, B. Increased performance of a tubular microbial fuel cell with a rotating carbon-brush anode. Biosens. Bioelectron. 2015, 63, 558-561. [CrossRef]

53. Zhang, M.; Ma, Z.K.; Zhao, N.; Zhang, K.X.; Song, H.H. Increased power generation from cylindrical microbial fuel cell inoculated with P. aeruginosa. Biosen. Bioelectron. 2019, 141, 111394. [CrossRef] [PubMed]

54. Wang, H.R.; Fu, B.Y.; Xi, J.Y.; Hu, H.Y.; Liang, P.; Huang, X.; Zhang, X.Y. Remediation of simulated malodorous surface water by columnar air cathode microbial fuel cells. Sci. Total Environ. 2019, 687, 287-296. [CrossRef] [PubMed]

55. Luo, Y.; Zhang, F.; Wei, B.; Liu, G.L.; Zhang, R.D.; Logan, B.E. Power generation using carbon mesh cathodes with different diffusion layers in microbial fuel cells. J. Power Sources 2011, 96, 9317-9321. [CrossRef]

56. Zhang, F.; Xia, X.; Luo, Y.; Sun, D.; Call, D.F.; Logan, B.E. Improving startup performance with carbon mesh anodes in separator electrode assembly microbial fuel cells. Bioresour. Technol. 2013, 133, 74-81. [CrossRef]

57. Huggins, T.; Wang, H.M.; Kearns, J.; Jenkins, P.; Ren, Z.J. Biochar as a sustainable electrode material for electricity production in microbial fuel cells. Bioresour. Technol. 2014, 157, 114-119. [CrossRef]

58. Fu, B.Y.; Xu, T.; Guo, X.G.; Liang, P.; Huang, X.; Zhang, X.Y. Optimization and simulation of a carbon-based flow-through composite anode configuration to enhance power generation and improve effluent quality simultaneously for microbial fuel cells. J. Clean. Prod. 2019, 229, 542-551. [CrossRef]

59. Chai, L.F.; Chai, L.C.; Suhaimi, N.; Son, R. Performance of air-cathode microbial fuel cell with wood charcoal as electrodes. Int Food Res. J. 2010, 17, 6.

60. Wang, B.; Han, J.I. A single chamber stackable microbial fuel cell with air cathode. Biotechnol. Lett. 2009, 31, 387-393. [CrossRef]

61. Menicucci, J.; Beyenal, H.; Marsili, E.; Veluchamy, R.A.; Demir, G.; Lewandowski, Z. Procedure for determining maximum sustainable power generated by microbial fuel cells. Environ. Sci. Technol. 2006, 40, 1062-1068. [CrossRef] [PubMed]

62. Yong, Y.C.; Dong, X.C.; Chan-Park, M.B.; Song, H.; Chen, P. Macroporous and monolithic anode based on polyaniline hybridized three-dimensional graphene for high-performance microbial fuel cells. ACS Nano 2012, 6, 2394-2400. [CrossRef]

63. Pareek, A.; Shanthi-Sravan, J.; Venkata-Mohan, S. Exploring chemically reduced graphene oxide electrode for power generation in microbial fuel cell. Mater. Sci. Technol. 2019, 2, 600-606. [CrossRef]

64. Wang, Z.B.; Ge, M.; Xiong, S.C.; Zhu, X.Q. Preparation of graphene/polyaniline-modified carbon nanotubes and their electrochemical properties in microbial fuel cell. Ionics 2017, 23, 1197-1202. [CrossRef]

65. Li, H.Y.; Liao, B.; Xiong, J.; Zhou, X.W.; Zhi, H.Z.; Liu, X.; Li, X.P.; Li, W.S. Power output of microbial fuel cell emphasizing interaction of anodic binder with bacteria. J. Power Sources 2018, 379, 115-122. [CrossRef]

66. Yang, S.; Jia, B.; Liu, H. Effects of the Pt loading side and cathode-biofilm on the performance of a membrane-less and singlechamber microbial fuel cell. Bioresour. Technol. 2009, 100, 1197-1202. [CrossRef] [PubMed] 
67. Moqsud, M.A.; Omine, K.; Yasufuku, N.; Hyodo, M.; Nakata, Y. Microbial fuel cell (MFC) for bioelectricity generation from organic wastes. Waste Manag. 2013, 33, 2465-2469. [CrossRef]

68. Yu, Y.Y.; Wang, Y.Z.; Fang, Z.; Shi, Y.T.; Cheng, Q.W.; Chen, Y.X.; Shi, W.; Yong, Y.C. Single cell electron collectors for highly efficient wiring-up electronic abiotic/biotic interfaces. Nat. Commun. 2020, 11, 4087. [CrossRef]

69. Kim, J.; Min, B.; Logan, B. Evaluation of procedures to acclimate a microbial fuel cell for electricity production. Appl. Microbiol. Biotechnol. 2005, 68, 23-30. [CrossRef]

70. Rosenbaum, M.; Schroder, U.; Scholz, F. Investigation of the electrocatalytic oxidation of formate and ethanol at platinum black under microbial fuel cell conditions. J. Solid State Electrochem. 2006, 10, 872-878. [CrossRef]

71. Rosenbaum, M.; Zhao, F.; Schröder, U.; Scholz, F. Interfacing electrocatalysis and biocatalysis with tungsten carbide: A highperformance, noble-metal-free microbial fuel cell. Angew. Chem. Int. Ed. 2006, 45, 6658-6661. [CrossRef] [PubMed]

72. Yuan, Y.; Kim, S. Improved Performance of a Microbial Fuel Cell with Polypyrrole/Carbon Black Composite Coated Carbon Paper Anodes. Bull. Korean Chem. Soc. 2008, 29, 5.

73. Adachi, M.; Shimomura, T.; Komatsu, M.; Yakuwa, H.; Miya, A. A novel mediator-polymer-modified anode for microbial fuel cells. Chem. Commun. 2008, 2055-2057. [CrossRef]

74. Chen, S.; Hou, H.; Harnisch, F.; Patil, S.A.; Carmona-Martinez, A.A.; Agarwal, S.; Zhang, Y.; Sinha-Ray, S.; Yarin, A.L.; Greiner, A.; et al. Electrospun and solution blown three-dimentional carbon fiber nonwovens for application as electrodes in microbial fuel cells. Energy Environ. Sci. 2011, 4, 1417-1421. [CrossRef]

75. Sun, M.; Zhang, F.; Tong, Z.H.; Sheng, G.P.; Chen, Y.Z.; Zhao, Y.; Chen, Y.P.; Zhou, S.Y.; Liu, G.; Tian, Y.C.; et al. A gold-sputtered carbon paper as an anode for improved electricity generation from a microbial fuel cell inoculated with Shewanella oneidensis MR-1. Biosens. Bioelectron. 2010, 26, 338-343. [CrossRef]

76. Yang, W.; Li, J.; Ye, D.; Zhu, X.; Liao, Q. Bamboo charcoal as a cost-effective catalyst for an air-cathode of microbial fuel cells. Electrochim. Acta 2017, 224, 585-592. [CrossRef]

77. Li, Z.; Haynes, R.; Sato, E.; Shields, M.; Fujita, Y.; Sato, C. Microbial community analysis of an a single chamber microbial fuel cell using potato wastewater. Water Environ. Res. 2014, 86, 324-330. [CrossRef]

78. Rizzoni, G. Principles and Applications of Electrical Engineering, 2nd ed.; IRWIN: Chicago, IL, USA, 1996; pp. 97-98.

79. Abedom, F.; Sakthivel, S.; Asfaw, D.; Melese, B.; Solomon, E.; Kumar, S.S. Development of natural fiber hybrid composites using sugarcane bagasse and bamboo charcoal for automotive thermal insulation materials. Adv. Mater. Sci. Eng. 2021, 2021, 2508840. [CrossRef]

80. Asada, T.; Ohkubo, T.; Kawata, K.; Oikawa, K. Ammonia adsorption on bamboo charcoal with acid treatment. J. Health Sci. 2006, 52, 585-589. [CrossRef]

81. Ho, M.; Lau, K.; Wang, H.; Hui, D. Improvement on the properties of polylactic acid (PLA) using bamboo charcoal particles. Compos. Part B Eng. 2015, 81, 14-25. [CrossRef]

82. Isa, S.S.M.; Ramli, M.M.; Hambali, N.A.M.A.; Kasjoo, S.R.; Isa, M.M.; Nor, N.I.M.; Khalid, N.; Ahmad, N. Adsorption properties and potential applications of bamboo charcoal: A review. In Proceedings of the MATEC Web of Conferences-IConGDM 2016, Amsterdam, The Netherlands, 23-25 March 2016; Volume 78, p. 01097. [CrossRef]

83. Liu, H.; Ao, H.; Xiong, X.; Xiao, J.; Liu, J. Arsenic removal from water by iron-modified bamboo charcoal. Water Air Soil Pollut. 2012, 223, 1033-1044. [CrossRef]

84. Lou, C.W.; Lin, C.W.; Lei, C.H.; Su, K.H.; Hsu, C.H.; Liu, Z.H.; Lin, J.H. PET/PP blend with bamboo charcoal to produce functional composites. J. Mater. Process Technol. 2007, 192, 428-433. [CrossRef]

85. Mousa, M.; Dong, Y.; Davies, I.J. Eco-friendly polyvinyl alcohol (PVA)/bamboo charcoal (BC) nanocomposites with superior mechanical and thermal properties. Adv. Compos. Mater. 2018, 27, 499-509. [CrossRef]

86. Park, S.H.; Wistara, N.J.; Febrianto, F.; Lee, M. Evaluation of sembilang bamboo (Dendrocalamus giganteus) charcoal for potential utilization. Bioresources 2020, 15, 6-19.

87. Wang, F.; Wang, H.; Ma, J. Adsorption of cadmium (II) ions from aqueous solution by a new low-cost adsorbent-bamboo charcoal. J. Hazard. Mater. 2009, 177, 300-306. [CrossRef]

88. Zhu, S.; Guo, Y.; Chen, Y.; Su, N.; Zhang, K.; Liu, S. Effects of the incorporation of nano-bamboo charcoal on the mechanical properties and thermal behavior of bamboo-plastic composites. Bioresources 2016, 11, 2684-2697. [CrossRef]

89. Zhang, J.; Li, J.; Ye, D.; Zhu, X.; Liao, Q.; Zhang, B. Tubular bamboo charcoal for anode in microbial fuel cells. J. Power Sources 2014, 272, 277-282. [CrossRef]

90. Scurlock, J.M.O.; Dayton, D.C.; Hames, B. Bamboo: An overlooked biomass resource? Biomass Bioenergy 2000, 19, 229-244. [CrossRef]

91. Li, P.; Zhou, G.; Du, H.; Lu, D.; Mo, L.; Xu, X.; Shi, Y.; Zhou, Y. Current and potential carbon stocks in Moso bamboo forests in China. J. Environ. Manag. 2015, 156, 89-96. [CrossRef]

92. Kim, B.; Mohan, S.V.; Fapyane, D.; Chang, I.S. Controlling voltage reversal in microbial fuel cells. Trends Biotechnol. 2020, 38, 667-678. [CrossRef]

93. An, J.; Lee, H.S. Occurrence and implications of voltage reversal in stacked microbial fuel cells. ChemSusChem 2014, 7, 1689-1695. [CrossRef] [PubMed]

94. Oh, S.E.; Logan, B.E. Voltage reversal during microbial fuel cell stack operation. J. Power Sources 2007, 167, 11-17. [CrossRef] 
95. Tan, W.H.; Chong, S.; Fang, H.W.; Pan, K.L.; Mohamad, M.; Lim, J.W.; Tiong, T.J.; Chan, Y.J.; Huang, C.M.; Yang, T.C.K. Microbial Fuel Cell Technology-A Critical Review on Scale-Up Issues. Processes 2021, 9, 985. [CrossRef]

96. He, Z.; Mansfel, F. Exploring the use of electrochemical impedance spectroscopy (EIS) in microbial fuel cell studies. Energy Environ. Sci. 2009, 2, 215-219. [CrossRef] 